\title{
Laminin Enriched Scaffolds for Tissue Engineering Applications
}

\begin{abstract}
Laminin (LM) is heterotrimeric large molecular weight glycoprotein that forms a crucial component of the basal lamina (or basement membrane) of most tissues. LMs are integral for cell adhesion, proliferation, survival, migration, and differentiation. Several studies have used a LM-coated 2D substrate for the culture and maintenance of stem cell phenotype in vitro. Recent studies have reported that LM can also be incorporated in 3D scaffolds for tissue engineering applications. This article illustrates the bioactivity and regenerative potential of LM protein in 3D scaffolds for skeletal muscle, nerve, vascular, and intervertebral-disc regeneration.
\end{abstract}

Volume 2 Issue 3 - 2017

\begin{abstract}
Muhamed Talovic, Madison Marcinczyk, Natalia Ziemkiewicz, Koyal Garg

Department of Biomedical Engineering, Saint Louis University, USA

Correspondence: Koyal Garg, Assistant Professor, Department of Biomedical Engineering, Parks College of Engineering, Aviation and Technology, Saint Louis University, 3507 Lindell Blvd., St. Louis, MO 63I 03, USA, Tel 314-977-8200,Email gargk@slu.edu
\end{abstract}

Abbreviations: ECM, extracellular matrix; LM, laminin; 3D, three-dimensional; VML, volumetric muscle loss; PDMS, polydimethylsiloxane; PEG, poly ethylene glycol; NMJ, neuromuscular junction; AchR, acetylcholine receptor; PGA, polyglycolic acid; NGF, nerve growth factor; PEGDA, PEG-diacrylate; PLLA, poly 1-lactic acid; SVZ, sub ventricular zone; CNS, central nervous system; SGZ, sub granular zone; TBI, traumatic brain injury; NPSC, neural progenitor/stem cells; SDF, stromal cell derived factor; IVD, the intervertebral disc; NP, nucleus pulposus

\section{Introduction}

Basement membranes are sheet-like extracellular matrix (ECM) structures that separate epithelium from the underlying connective tissue and surround nerve, muscle, and vessel cells. ${ }^{1}$ The basement membrane provides mechanical stability and plays crucial roles in cell differentiation, survival, and migration. Major components of the basement membrane include collagen type IV and a heterotrimeric glycoprotein, laminin (LM). ${ }^{2} \mathrm{LM}$ is composed of three chains $(\alpha, \beta$ and $\gamma$ ) that are known to spontaneously self-assemble into hexagonal networks in vitro through calcium dependent interactions. ${ }^{3}$ LM exists in multiple isoforms in different tissues. Five $\alpha$ chains, three $\beta$ chains and three $\gamma$ chains have so far been identified. Combinations of these chains lead to the formation of 16 different LM isoforms with tissue-specific functions. For example, LM-111 $\left(\alpha_{1} \beta_{1} \gamma_{1}\right.$ or LM-1) is expressed in epithelium and endothelium, LM-211 $\left(\alpha_{2} \beta_{1} \gamma_{1}\right.$ or LM-2) is present in striated muscle and peripheral nerves, LM-121 $\left(\alpha_{1} \beta_{2} \gamma_{1}\right.$ or LM-3) exists in synapse and glomerulus, LM-221 ( $\alpha_{2} \beta_{2} \gamma_{1}$ or LM-4) is expressed in myotendinous junction, and LM-332 ( $\alpha_{3} \beta_{3} \gamma_{2}$ or LM-5) is found in skin and mucous membranes. ${ }^{3,4}$ The distribution of LM-111 in adult tissues is limited and it is primarily expressed during fetal and embryonic development. ${ }^{5} \mathrm{LM}$ has been incorporated in threedimensional (3D) scaffolds for the regeneration of several different tissues such as skeletal muscle, nerve, intervertebral-disc, and blood vessels. Some recent findings are summarized in this article.

\section{Skeletal muscle regeneration}

LM is a structural protein in the ECM of skeletal muscle fibers that provides an important scaffold for tissue development, maintenance, and function. ${ }^{6}$ Satellite cells and myoblasts express the $\alpha_{7} \beta_{1}$ integrin and interact with LM in the basal lamina. LM influences satellite cell proliferation, adhesion, migration, and differentiation..$^{7-10}$ and LMdeficient $(\mathrm{dy} / \mathrm{dy})$ mice are reported to lose their endogenous capacity for regeneration. ${ }^{11-13} \mathrm{LM}-111$ is one of the first proteins expressed during embryogenesis and is associated with a variety of biological activities, including stem cell migration, nerve growth, angiogenesis, matrix remodeling, and basement membrane assembly. ${ }^{14}$ LM-111 supplementation has demonstrated remarkable regenerative capacity in several models of muscular disease ${ }^{15-17}$ and injury ${ }^{18}$ primarily by enhancing satellite cell activity. In mice with congenital muscular dystrophy due to missing LM $\alpha_{2}$ chains, overall health and survival can be improved by administration of LM $\alpha 1$ chains, ${ }^{19,20}$ In vitro, LM111 promotes muscle stem cell proliferation and differentiation to a greater extent than other ECM components such as collagen type I and fibronectin. ${ }^{21}$ The development of LM enriched 3D scaffolds will be useful for the treatment of large muscle defects in cases of volumetric muscle loss (VML) where long-term structural and mechanical support is required for there generating muscle tissue. ${ }^{22-25}$ Given the therapeutic efficacy of LM in skeletal muscle regeneration, studies incorporating $\mathrm{LM}$ in tissue engineered $3 \mathrm{D}$ scaffolds are critically needed to improve orthopedic care of musculoskeletal trauma.

Dennis and Kosnik engineered 3D skeletal muscle tissue constructs termed myooids by culturing primary skeletal muscle myoblasts on a LM coated $\left(0.5-1.5 \mu \mathrm{g} / \mathrm{cm}^{2}\right)$ SYLGARD substrate with anchor points composed of decellularized muscle or LM coated silk suture. ${ }^{26}$ After 2-3 weeks of culture, the monolayer of myotubes in each dish detached from the SYLGARD substrate and rolled into a cylinder while only remaining attached to the anchor points. Once formed, these myooids produced a twitch force of $215 \mu \mathrm{N}$, maximum isometric force of $440 \mu \mathrm{N}$ and a specific force of $2.9 \mathrm{kN} / \mathrm{m}^{2}$ in response to electrical stimulation in vitro.

Using a similar concept, micro-patterned substrates of polydimethylsiloxane (PDMS) were coated with LM at a density of $2 \mu \mathrm{g} / \mathrm{cm}^{2}$ to provide an aligned and adhesive substrate for primary myoblast differentiation. ${ }^{27} \mathrm{LM}$ coated silk sutures were pinned into the PDMS plates to serve as anchor points. Fibrin gel $(20 \mathrm{mg} / \mathrm{ml})$ was added on top of the confluent myotubes to facilitate cell detachment 
from the substrate into a single intact cylindrical layer between the anchor points. The pre-aligned skeletal muscle constructs stained positive for myosin heavy chain and produced significantly higher contractile forces compared to unaligned constructs. The pre-aligned muscle constructs produced a peak twitch force of $215 \mu \mathrm{N}$, peak tetanus force of $411 \mu \mathrm{N}$, and specific force of $8.10 \mathrm{kN} / \mathrm{m}^{2}$ in vitro.

Bursac and co-workers created bioengineered myobundles composed of fibrinogen $(4 \mathrm{mg} / \mathrm{ml})$ and matrigel $(40 \%)$ mixed with neonatal rat derived skeletal muscle myoblasts. ${ }^{28}$ The myobundles were held under tension during culture and resulted in the formation of highly aligned and cross-striated myotubes $\left(\alpha 7\right.$ integrin $^{+}$and $\alpha$-actinin $\left.{ }^{+}\right)$ that were capable of isometric force production $(\sim 3 \mathrm{mN})$. The increase in myofiber hypertrophy and prolongation of intracellular calcium transients in the bioengineered myobundles provided the mechanistic basis for the high levels of contractile force generation in vitro. In a subsequent study, Bursac and co-workers modified the biomimetic hydrogels by combining $20 \mathrm{mg} / \mathrm{ml}$ fibrinogen with $\sim 32 \%$ matrigel and human skeletal muscle myoblasts. ${ }^{29}$ The myobundles were reported to generate electrically induced calcium transients and tetanic contractions (specific force $7 \mathrm{mN} / \mathrm{mm}^{2}$ ) as well as force-length and force-frequency relationships, recapitulating key functional aspects of human skeletal muscle. Additionally, the myobundles maintained functional acetylcholine receptors and underwent dose-dependent hypertrophy or toxic myopathy in response to pharmacological treatments in vitro.

In another study, LM was covalently cross-linked at a density of $7.6 \mathrm{ng} / \mathrm{cm}^{2}$ to a poly (ethylene glycol) (PEG) hydrogels. ${ }^{30}$ Hydrogels that mimicked the native elasticity of skeletal muscle $(\sim 12 \mathrm{kPa})$ promoted skeletal muscle derived satellite cell renewal in culture. The study further showed that muscle satellite cells cultured on LM functionalized pliant hydrogels are able to support extensive muscle regeneration when implanted into immune deficient mice depleted of endogenous satellite cells by irradiation. However, the study did not evaluate functional improvements in the skeletal muscle following cell transplantation. Taken together, these studies demonstrate that LM can be blended, coated or covalently cross linked on 3D scaffolds to support functional skeletal muscle regeneration.

\section{Peripheral nervous system regeneration}

Besides influencing satellite cell activity, LM-111 is also crucial for maintaining nerve cells in peripheral nerves ${ }^{31}$ and serves as a major substrate for neurite extension ${ }^{32}$ and axon growth, ${ }^{33}$ both in vivo and in vitro. After peripheral nerve injury, LM production by Schwann cells at the injury site is up regulated to promote axonal regeneration. Mice lacking LM $\alpha_{2}$ chain show impaired axon myelination due to reduced Schwann cell proliferation. Similarly, humans suffering from congenital muscular dystrophy due to the lack of LM $\alpha_{2}$ develop demyelinating peripheral neuropathy. ${ }^{34}$ The absence of $\mathrm{LM}$ also results in impaired neuromuscular junction (NMJ) development. ${ }^{35-37}$ and exogenous LM-111 supplementation promotes acetylcholine receptor (AChR) clustering and functional NMJ formation in vitro. ${ }^{7,21,38} \mathrm{LM}$ and agrin can act together to enhance the number, size, and rate of AChR clusters. ${ }^{38,39} \mathrm{LM}$ also mediates the interaction between integrin $\alpha_{7} \beta$ and the neural AChR clusters on the muscle membrane, potentially stabilizing them and allowing them to be more readily innervated by the incoming neurite. ${ }^{40}$ As a result, LM based neurogenic materials have been widely used as peripheral nerve grafts in several studies.
A number of studies have combined LM with collagen to create 3D scaffolds for peripheral nerve regeneration (Table 1). Harkins and co-workers studied the impact of LM $(0-100 \mu \mathrm{g} / \mathrm{ml})$ on 3D neurite extension in neurons dissociated from E9 chick dorsal root ganglion in collagen $(0.4-2.0 \mathrm{mg} / \mathrm{ml})$ gels. ${ }^{41} \mathrm{LM}$ was shown to associate homogenously with collagen fibers and did not alter the mechanical properties of the collagen gels. Neurite outgrowth was greater on gels composed of lower collagen $(0.4-0.8 \mathrm{mg} / \mathrm{ml})$ and LM $(1-10 \mu \mathrm{g} /$ $\mathrm{ml}$ ) concentrations, indicating a dose-dependent effect of ECM components on neuron differentiation and neurite out growth.

Toba et al. ${ }^{42}$ developed a novel nerve conduit composed of polyglycolic acid (PGA)-collagen tube filled with human LM (10g/ $\mathrm{ml}$ ) soaked collagen sponge that was implanted into an 80-mm gap of peroneal nerve in dogs. At 12 months post-surgery, the conduit was completely absorbed and a high density of myelinated axons could be observed in the regenerated nerve segment. Electrophysiological studies showed that both motor and sensory nerves had partially regenerated and re-established electrical connections with their target tissues. Since LM is known to promote nerve regeneration directly, the authors hypothesized that local release of LM from the collagen sponge may have accelerated the regeneration of elongating axons that were able to bridge the wide neural defect and form connections with the distal nerve stump while the implanted guiding conduit was still intact.

In a recent study, a scaffold combining collagen with LM was able to promote greater nerve regeneration in a rat model of recurrent laryngeal nerve injury compared to pure collagen scaffold. ${ }^{43}$ The functional recovery matched that of autologous nerve grafts when LM was used in combination with collagen. Although motor function was not restored, injuries treated with the collagen tube loaded with LM and also LM binding neurotrophic factors was able to improve vocalization, arytenoid cartilage angles, compound muscle action potentials, and regenerated nerve fiber area in comparison to the autograft treated group.

Suri et al. ${ }^{44}$ fabricated hydrogels composed of hyaluronic acid, collagen and LM for the encapsulation of Schwann cells. The encapsulated cells showed higher metabolic activity and proliferation on LM enriched hydrogels. The Schwann cells also secreted highest levels of neurogenic growth factors such as nerve growth factor (NGF) and brain derived neurotrophic factor (BDNF) in hydrogels that contained LM. Cells in the LM enriched hydrogels were also found to align parallel to each other and form structures called Bands of Bungner suggesting the formation of oriented channels for axonal guidance and synapse formation. Furthermore, the hydrogel matrix was shown to support the co-culture of Schwann cells and neurons.

LM has also been combined with synthetic polymers such as PEG for peripheral nerve regeneration. PEG-LM111 hydrogels were synthesized by reacting them with PEG-diacrylate (PEGDA) in the presence of irgacure as an initiator. ${ }^{45}$ In contrast to findings reported by other studies, ${ }^{46}$ the hydrogel stiffness decreased with increasing concentrations of PEG-LM111 conjugates. Hydrogel encapsulated dorsal root ganglion exhibited longer neurite extensions with increasing LM111 concentration $(0-100 \mu \mathrm{g} / \mathrm{ml})$. The authors reported no difference between LM111 conjugation and encapsulation within the PEG hydrogels confirming that chemical conjugation had minimal effect on the LM111 protein structure and bioactivity. Interestingly, the study also showed that LM concentration had a greater impact on neurite extensions than the stiffness of the gels. 
In addition to hydrogels, LM has also been combined with electrospun nanofibers. LM was combined with poly (1-lactic acid) (PLLA) nanofibers using covalent binding $(\sim 1.75 \mu \mathrm{g} /$ $\mathrm{mg}$ of PLLA), physical adsorption $(\sim 1.50 \mu \mathrm{g} / \mathrm{mg}$ of PLLA), and blended electrospinning $(\sim 3.12 \mu \mathrm{g} / \mathrm{mg}$ of PLLA $){ }^{47}$ LM modified PLLA scaffolds supported better PC12 cell viability and adhesion compared to unmodified nanofibers. Additionally, blended LM-PLLA nanofibers promoted greater neurite outgrowth compared to surface modified nanofibers. Three-dimensional incorporation of LM into PLLA scaffolds resulted in greater overall concentration and better cellular interaction. Taken together, these studies suggest that LM can be combined with a wide range of natural and synthetic materials to support the proliferation and maturation of Schwann cells and neurons for peripheral nerve regeneration.

Table I Number of studies have combined LM with collagen to create 3D scaffolds for peripheral nerve regeneration

\begin{tabular}{|c|c|c|c|c|}
\hline Scaffold composition & $\begin{array}{l}\text { Morphological } \\
\text { properties }\end{array}$ & $\begin{array}{l}\text { Mechanical } \\
\text { properties }\end{array}$ & Cell and tissue interactions & Reference \\
\hline \multicolumn{5}{|l|}{ Skeletal muscle regeneration } \\
\hline $\begin{array}{l}\text { PEG functionalized with } \\
\mathrm{LM}\left(7.6 \mathrm{ng} / \mathrm{cm}^{2}\right)\end{array}$ & N/A & $\begin{array}{l}\text { Elastic modulus } \\
\sim 12 \mathrm{kPa}\end{array}$ & $\begin{array}{l}\text { Hydrogels mimicked native tissue elasticity and enhanced satellite } \\
\text { cell renewal in vitro. Implantation of hydrogels in satellite cell } \\
\text { deficient mice supported extensive muscle fiber regeneration. }\end{array}$ & 67 \\
\hline $\begin{array}{l}\text { Fibrinogen }(4 \mathrm{mg} / \mathrm{ml})+\text { Matrigel } \\
(40 \%)\end{array}$ & N/A & $\mathrm{N} / \mathrm{A}$ & $\begin{array}{l}\text { Hydrogels supported aligned and cross-striated myofiber } \\
\text { formation from encapsulated myoblasts and generated contractile } \\
\text { force }(\sim 3 \mathrm{mN}) \text { in vitro. }\end{array}$ & 28 \\
\hline $\begin{array}{l}\text { Fibrinogen }(20 \mathrm{mg} / \\
\mathrm{ml})+ \text { Matrigel }(\sim 30 \%)\end{array}$ & N/A & $\mathrm{N} / \mathrm{A}$ & $\begin{array}{l}\text { Hydrogels supported striated myofiber formation from human } \\
\text { myoblasts and produced specific force of } 7 \mathrm{mN} / \mathrm{mm}^{2} \text { for } \\
\text { tetanus. Myobundles exhibited physiological responsiveness to } \\
\text { pharmaceutical treatment. }\end{array}$ & 29 \\
\hline $\begin{array}{l}\text { LM coated }\left(0.5-1.5 \mu \mathrm{g} / \mathrm{cm}^{2}\right) \\
\text { SYLGARD dish with LM } \\
\text { coated anchor points }\end{array}$ & N/A & $\mathrm{N} / \mathrm{A}$ & $\begin{array}{l}\text { Monolayer of rat myoblasts rolled into a cylindrical structure } \\
\text { called myooid that produced a specific force of } 2.9 \mathrm{kN} / \mathrm{m}^{2} \text { in } \\
\text { response to electrical stimulation. }\end{array}$ & 26 \\
\hline $\begin{array}{l}\text { LM }\left(2 \mu \mathrm{g} / \mathrm{cm}^{2}\right) \text { coated micro } \\
\text { patterned PDMS with anchor } \\
\text { points and fibrin gel }(20 \mathrm{mg} / \mathrm{ml})\end{array}$ & N/A & $\mathrm{N} / \mathrm{A}$ & $\begin{array}{l}\text { Fibrin gels were used to detach a monolayer of aligned myotubes } \\
\text { cultured on micro patterned PDMS, which rolled into a cylindrical } \\
\text { construct between the anchor points and produced a specific } \\
\text { force of } 8.10 \mathrm{kN} / \mathrm{m}^{2} \text { in vitro. }\end{array}$ & 27 \\
\hline \multicolumn{5}{|l|}{ CNS regeneration } \\
\hline $\begin{array}{l}\mathrm{LM}(10 \mu \mathrm{g} / \mathrm{ml}) \text { rich gelatin }(3 \%) \\
\text { sponge }\end{array}$ & N/A & $N / A$ & $\begin{array}{l}\text { Transplanted sponge supported neuroblast migration and } \\
\text { suppressed microglial invasion into cortical lesions of mice. }\end{array}$ & 50 \\
\hline $\begin{array}{l}\text { LM }(0.01 \% \mathrm{w} / \mathrm{v}) \text { and gelatin }(4.4 \\
\% \mathrm{w} / \mathrm{v}) \text { cryogel }\end{array}$ & $\begin{array}{l}\text { Mean pore size } \\
\text { of } 80-120 \mu \mathrm{m}\end{array}$ & N/A & $\begin{array}{l}\text { Cryogels promoted human cord blood-derived stem cells } \\
\text { differentiation into neural tissue-like structures in vitro. Cryogel } \\
\text { implantation in rat brain cortex supported neuroblast infiltration. }\end{array}$ & 52 \\
\hline $\begin{array}{l}\text { LM-I I I }(\sim 1.6 \mathrm{ng} / \mathrm{mg}) \text { tethered } \\
\text { to methylcellulose to form a } \\
\text { hydrogel }\end{array}$ & N/A & $\begin{array}{l}\text { Complex } \\
\text { moduli } 79-155.9 \\
\mathrm{~Pa}\end{array}$ & $\begin{array}{l}\text { Thermo responsive injectable hydrogel enhanced primary rat } \\
\text { cortical neuron adhesion and survival. }\end{array}$ & 52 \\
\hline $\begin{array}{l}\text { LM-I I I }(0.015 \% \\
w / v)+ \text { hyaluronic acid }(I .75 \% \\
w / v) \text { hydrogels }\end{array}$ & $\begin{array}{l}\text { Pore size } \\
\text { ranging from } \\
2-17 \mu \mathrm{m}\end{array}$ & $\begin{array}{l}\text { Storage } \\
\text { modulus of } \\
1.02 \mathrm{kPa}\end{array}$ & $\begin{array}{l}\text { Hydrogels supported NPSCs viability and up regulated their } \\
\text { chemotactic migration in response to SDF-I a in vitro. }\end{array}$ & 53 \\
\hline $\begin{array}{l}\text { Hyaluronic acid }(\mathrm{l} \mathrm{mg/ml})+\mathrm{LM} \\
(500 \mathrm{ng} / \mathrm{ml})\end{array}$ & $\begin{array}{l}\text { Pore-size } \\
\text { ranging from } \\
6-60 \mu \mathrm{m}\end{array}$ & $\begin{array}{l}\text { Complex } \\
\text { modulus } \sim 400 \\
\mathrm{~Pa}\end{array}$ & $\begin{array}{l}\text { Transplantation of hydrogels in a rat brain lesion showed } \\
\text { astrocyte and microglial infiltration, angiogenesis, neurite } \\
\text { extension and regeneration of myelinated nerve fibers }\end{array}$ & 68 \\
\hline $\begin{array}{l}\text { LM }(100 \mu g / m l)+\text { hyaluronic } \\
\text { acid }(\mathrm{I} \mathrm{mg} / \mathrm{ml})+\text { fibrin }(5 \mathrm{mg} / \mathrm{ml}) \\
\text { hydrogels }\end{array}$ & N/A & $\mathrm{N} / \mathrm{A}$ & $\begin{array}{l}\text { Hydrogels enhanced neurite outgrowth from differentiating } \\
\text { NPSCs and enhanced angiogenesis from endothelial cells in co- } \\
\text { cultures. }\end{array}$ & 55 \\
\hline \multicolumn{5}{|l|}{ PNS Regeneration } \\
\hline $\begin{array}{l}\mathrm{LM}(\mathrm{I} 0 \mu \mathrm{g} / \mathrm{ml})+\text { collagen }(0.4-0.8 \\
\mathrm{mg} / \mathrm{ml})\end{array}$ & N/A & $\begin{array}{l}\text { Modulus:10- } \\
\text { I00dyn/cm2 }\end{array}$ & $\begin{array}{l}\text { Hydrogels supported neurite extension from dorsal root ganglion } \\
\text { in a dose dependent manner. }\end{array}$ & $4 I$ \\
\hline $\begin{array}{l}\text { PGA-collagen tube filled with } \\
\text { human LM }(10 \mathrm{~g} / \mathrm{ml}) \text { soaked } \\
\text { collagen sponge }\end{array}$ & N/A & $\mathrm{N} / \mathrm{A}$ & $\begin{array}{l}\text { Implantation of LM-collagen sponge in dogs enhanced nerve } \\
\text { regeneration across } 80-\mathrm{mm} \text { wide neural defect, with partial } \\
\text { motor and sensory function recovery. }\end{array}$ & 43 \\
\hline $\begin{array}{l}\text { Collagen tube loaded with LM } \\
\text { and LM binding neurotrophic } \\
\text { factors }\end{array}$ & $\begin{array}{l}\text { Mean pore size } \\
\text { of } 60 \pm 4 \mu \mathrm{m} \text {. }\end{array}$ & $\mathrm{N} / \mathrm{A}$ & $\begin{array}{l}\text { Transplantation of scaffold in a rat model of laryngeal nerve injury } \\
\text { improved vocalization, arytenoid cartilage angles, compound } \\
\text { muscle action potentials and regenerated nerve fiber area. }\end{array}$ & 44 \\
\hline $\begin{array}{l}\text { Collagen, Hyaluronic acid and } \\
\text { LM }(100 \mu g / m l)\end{array}$ & N/A & $\mathrm{N} / \mathrm{A}$ & $\begin{array}{l}\text { Encapsulated Schwann cells increased NGF and BDNF secretion } \\
\text { in the presence of LM. }\end{array}$ & 45 \\
\hline
\end{tabular}




\begin{tabular}{|c|c|c|c|c|}
\hline Scaffold composition & $\begin{array}{l}\text { Morphological } \\
\text { properties }\end{array}$ & $\begin{array}{l}\text { Mechanical } \\
\text { properties }\end{array}$ & Cell and tissue interactions & Reference \\
\hline $\begin{array}{l}\text { PEGDA(3\%)+PEGLM( } 100 \mu g / \\
\mathrm{ml})\end{array}$ & N/A & $\begin{array}{l}\text { Mechanical } \\
\text { stiffness, } \sim 70 \mathrm{~Pa}\end{array}$ & $\begin{array}{l}\text { Hydrogels supported longest neurite extension from dorsal root } \\
\text { ganglion dissociated neurons. }\end{array}$ & 45 \\
\hline $\begin{array}{l}\text { LM electrospun with } \\
\text { PLLA(3.12 } \mu \mathrm{g} / \mathrm{mg})\end{array}$ & N/A & N/A & $\begin{array}{l}\text { LM modified PLLA scaffolds supported greater PCI } 2 \text { cell viability } \\
\text { and adhesion and greater neurite extension compared to plain } \\
\text { PLLA scaffolds. }\end{array}$ & 69 \\
\hline \multicolumn{5}{|l|}{ IVD regeneration } \\
\hline $\begin{array}{l}\text { PEG-octoacrylate and PEG- } \\
\text { dithiol + PEGLMI I I conjugates } \\
(500 \mu \mathrm{g} / \mathrm{ml})\end{array}$ & N/A & $\begin{array}{l}\text { Elastic Modulus, } \\
1200-1500 \mathrm{~Pa}\end{array}$ & $\begin{array}{l}\text { Hydrogels significantly improved encapsulated porcine NP cell } \\
\text { survival and retention over a I } 4 \text { day period in rat IVD explants. }\end{array}$ & 58 \\
\hline $\begin{array}{l}\text { PEG and LM }(2 \mathrm{mg} / \mathrm{ml})(25: \text { I } \\
\text { molar ratio) }\end{array}$ & N/A & $\begin{array}{l}\text { Shear modulus, } \\
0.9-1.4 \mathrm{kPa}\end{array}$ & $\begin{array}{l}\text { Hydrogels supported primary NP cell survival and GAG } \\
\text { synthesis. Encapsulated NP cells showed increased expression of } \\
\mathrm{N} \text {-cadherin and cytokeratin-8. }\end{array}$ & 45 \\
\hline \multicolumn{5}{|l|}{ Vascular regeneration } \\
\hline $\begin{array}{l}\text { Collagen }(2 \mathrm{mg} / \mathrm{ml})+\mathrm{LM}-5 \\
(50 \mu \mathrm{\mu g} / \mathrm{ml}) \text { hydrogels }\end{array}$ & $\mathrm{N} / \mathrm{A}$ & N/A & $\begin{array}{l}\text { Hydrogels interspersed with HUVECs and HBMSCs supported } \\
\text { cell proliferation and formation of tubular network }\end{array}$ & 60 \\
\hline $\begin{array}{l}\text { ePTFE functionalized with } \\
\text { LM-I }\left(25 \mu \mathrm{g} / \mathrm{cm}^{2}\right)\end{array}$ & N/A & N/A & $\begin{array}{l}\text { LM immobilized small diameter ePTFE vascular grafts remained } \\
\text { patent and supported neovascularization and endothelialization } 5 \\
\text { weeks post-implantation in a rat model. }\end{array}$ & 61 \\
\hline
\end{tabular}

\section{Central nervous system regeneration}

Neurogenesis occurs in two specialized niches of the brain which are localized in the sub granular zone (SGZ) of the dentate gyrus in the hippocampus and the sub ventricular zone (SVZ) of the lateral ventricles of the human brain. ${ }^{48}$ In both zones, neurogenesis is closely associated with angiogenesis. LM is a major component of the basement membrane of blood vessels in the central nervous system (CNS) and is responsible for regulating neuronal migration and neurite outgrowth. Neural stem cells receive signals from interstitial LM and from the fingerlike processes of the basal lamina called fractones, which extend from blood vessels. ${ }^{49}$ These integrin mediated cellular interactions with LM are vital for neuronal proliferation, survival, migration and differentiation. ${ }^{32}$

Lack of effective therapies to restore lost brain neurons following stroke or injury presents a significant opportunity to develop clinically relevant neurogenic materials. Ajioka et al..$^{50}$ created LM containing porous gelatin sponges for enhancing neuroblast migration in a rodent model of traumatic brain injury (TBI). LM concentration of $10 \mu \mathrm{g} /$ $\mathrm{ml}$ was sufficient to elicit astrocyte and neuroblast migration into the cortical lesions and suppress microglial cell invasion. Moreover, LM enriched sponges were wrapped with astrocytic processes, resembling the structure of blood vessels in the CNS.

Jurga et al..$^{51}$ created cryogels containing LM $(0.01 \% \mathrm{w} / \mathrm{v})$ and fish skin gelatin $(4.4 \% \mathrm{w} / \mathrm{v})$ that were crosslinked with glutaraldehyde for mechanical stability. In hippocampal organotypic cultures, the gelatinLM cryogels showed intensive migration of NF200 $0^{+}$neuroblasts throughout the entire volume of the scaffold. $\mathrm{GFAP}^{+}$glial cells were found constricted to the periphery of the scaffold and did not form dense scars typical of brain tissue lesion. Additionally, LM-rich cryogels did not promote microglial cell activation and infiltration into the scaffolds. The authors observed a similar integration process following cryogel implantation in the rat brain cortex following TBI. The cryogels also promoted neuronal differentiation of human cord blood derived stem cells and formation of neural niche-like structures in vitro.
Stabenfeldt et al. ${ }^{52}$ tethered $\sim 1.6 \mathrm{ng}$ of LM-111 per $\mathrm{mg}$ of methylcellulose to create a thermo responsive hydrogel for neural tissue engineering. The hydrogel was formed without a free radical initiator to avoid potential cytotoxic effects and could be delivered via minimally invasive techniques. Primary rat cortical neurons showed increased adhesion and survival on LM-111 functionalized hydrogels compared to unfunctionalized controls. Overall, the study showed that a bioactive and injectable hydrogel that could gel in situ could offer significant advantages in treating CNS trauma, where an irregularly shaped lesion cavity often poses structural and integration difficulties for pre-formed tissue engineered constructs.

To overcome issues of low survival and viability posttransplantation of neural progenitor/stem cells (NPSC) in traumatic brain injury, Addington et al. $^{53}$ synthesized LM immobilized hyaluronic acid (HA) hydrogels for NPSC delivery and engraftment. Hydrogels containing high concentrations of LM $(0.015 \% \mathrm{w} / \mathrm{v})$ and low concentrations of HA $(1.75 \% \mathrm{w} / \mathrm{v})$ mimicked the stiffness of native neural tissue $(1.02 \mathrm{kPa})$ and supported greater NPSC density, viability, and chain length. The HA-LM hydrogels up regulated CXCR4 expression in NPSCs after 48 hours of culture and promoted their chemotactic migration in response to stromal cell derived factor (SDF)-1 $\alpha$ gradients. Taken together, these results suggest that implantation of a HA-LM hydrogel can enhance the delivery and migration of NPSC in an injured microenvironment.

In another study, LM $(500 \mathrm{ng} / \mathrm{ml})$ was cross-linked onto the backbone of hyaluronic acid hydrogels. Both LM modified and unmodified hydrogels were evaluated for their ability to repair and regenerate CNS after trauma. 6 and 12 weeks after implantation, both hydrogels were found well integrated with the host tissue. The scaffolds showed astrocyte and microglial infiltration as well as angiogenesis but only LM modified scaffolds showed neurite outgrowth and the presence of myelinated nerve fibers in the regenerating tissue. ${ }^{54}$

Arulmoli et al. ${ }^{55}$ combined fibrin, HA and LM $(100 \mu \mathrm{g} / \mathrm{ml})$ to create combination scaffolds for the purpose of NPSC transplantation following CNS injury. The addition of LM significantly improved neurite outgrowth from differentiating NPSCs. The presence of LM 
and NPSCs in the scaffolds synergistically enhanced angiogenesis from endothelial cells. Co-culture of NPSCs with human cord bloodderived endothelial cells on the composite scaffolds containing LM yielded the highest vessel area percentage, total vessel length, and significantly more branch points.

\section{Intervertebral disc regeneration}

The intervertebral disc (IVD) is composed of a thick outer ring of fibrous cartilage termed the annulus fibrosus, which encapsulates a gelatinous core known as the nucleus pulposus (NP). The NP contains collagen and elastin fibers embedded in an aggrecancontaining gel. ${ }^{56}$ Age associated degeneration of IVD originates in the NP region and is characterized by decreased water-content, cellularity as well as proteoglycan and ECM composition resulting in impaired ability of the tissue to resist and redistribute compressive loads. ${ }^{57} \mathrm{NP}$ cells are known to cluster and produce more proteoglycan rich matrix when cultured on soft $(<0.5 \mathrm{kPa})$ LM rich substrates as compared to fibronectin or collagen..$^{57}$ Francisco et al. ${ }^{58}$ developed injectable, LM-111 functionalized PEG hydrogels by combining PEG-LM111 conjugates with PEG-octoacrylate and PEG-dithiol under physiological conditions. Bioluminescence studies showed that PEG-LM111 hydrogels significantly improved encapsulated NP cell survival and retention over a 14 day period in IVD explants.

In a subsequent study, Fransisco et al. ${ }^{46}$ synthesized photocrosslinkablePEG-LM111 hydrogels for IVD regeneration. Increasing the degree of LM modification was found to alter LM bioactivity and inhibit immature NP cell adhesion. The stiffness of the hydrogels was shown to increase with increasing concentrations of PEG-LM111 conjugates. Primary NP cells formed large multi cell clusters and increased glycosaminoglycan (GAG) synthesis when cultured on soft PEG-LM111 hydrogels. Cell encapsulation in 3D PEG-LM111 hydrogels was found to influence NP metabolism and stimulated higher expression of $\mathrm{N}$-cadherin and cytokeratin 8 . These studies provide evidence that LM111 enriched soft substrates can positively influence NP cell proliferation and function for treating age-associated IVD degeneration.

\section{Vascular regeneration}

Rapid vascularization of tissue engineered grafts is important for regeneration. Restoration of blood flow in peripheral vascular disease and stroke is crucial for the survival of ischemic tissues. LM is a major biologically active component of the vascular basement membrane that promotes endothelial cell adhesion, migration, and differentiation to support angiogenesis. ${ }^{59}$

Stamati et al. ${ }^{60}$ fabricated type 1 collagen hydrogels supplemented with of $50 \mu \mathrm{g} / \mathrm{ml}$ of LM-5. The hydrogels were interspersed with human umbilical vein endothelial cells (HUVECs) and bone marrow derived mesenchymal stem cells (HBMSCs) throughout the matrix to recapitulate the in vivo 3D microenvironment of a vascular niche. While collagen hydrogels supported cobblestone morphology in HUVECs, the addition of LM resulted in HUVEC aggregation and formation of large end-to-end tubular networks. The authors attributed the formation of these tubular structures to the increased expression of $\alpha_{6}$ integrin and vascular endothelial growth factor receptor 2(VEGFR2) in HUVECs as well as enhanced VEGF uptake by the cells in the presence of LM-5.

Surface modification with LM is also reported to enhance anticoagulant and endothelialization properties of vascular grafts. LM-111 was covalently immobilized on the surface of synthetic polymeric vascular grafts such as expanded poly tetra fluoroethylene (ePTFE) ${ }^{61}$ These LM modified small diameter vascular grafts were tested as interpositional aortic grafts in a rat model. At 5 weeks post-implantation, the LM modified grafts showed increased neovascularization and endothelialization compared to unmodified ePTFE. LM modified grafts also remained anti thrombogenic and patent and did not show evidence of intimal thickening, overcoming the disadvantages commonly associated with small diameter synthetic vascular grafts. In another example, co-immobilization of LM and fucoidan, a sulfated polysaccharide, on a glass substrate improved endothelial cell proliferation but inhibited smooth muscle cell growth and platelet adhesion. ${ }^{62}$ Taken together, these studies suggest that surface modification with LM can enhance the anticoagulant properties and endothelialization of vascular grafts.

\section{Conclusion}

LM has been successfully combined with several synthetic and natural polymers in $3 \mathrm{D}$ scaffolds to promote tissue regeneration. The studies reviewed in this article illustrate that LM concentration and method of incorporation into the 3D scaffold can greatly influence its bioactivity and capacity for regeneration. A number of studies have used short peptide sequences from LM chains to promote cellular activity in $3 \mathrm{D}$ scaffolds. ${ }^{63-66}$ While these short peptides are more stable and easily synthesized, they do not recapitulate the 3D microenvironment of the stem cell niche in adult tissues. Matrigel is often used in tissue engineered scaffolds as it contains high concentration of LM. However, the concentration of LM in Matrigel is variable and cannot be precisely controlled for dose-dependent effects. Additionally, both Matrigel and LM are commonly isolated and purified from rodent tissue which is a major impediment to their clinical translation. Thorough evaluation of the regenerative potential of full-length human LM enriched scaffolds in large animal models will pave the way for clinical translation of this therapeutic protein.

\section{Acknowledgements}

None.

\section{Conflict of interest}

The author declares no conflict of interest.

\section{References}

1. Sasaki T, Fässler R, Hohenester E. Laminin: the crux of basement membrane assembly. J Cell Biol. 2004;164(7):959-963.

2. Timpl R, Rohde H, Robey PG, et al. Laminin-a glycoprotein from basement membranes. J Biol Chem. 1979;254(19):9933-9937.

3. Ryan MC, Christiano AM, Engvall E, et al. The functions of laminins: lessons from in vivo studies. Matrix Biol. 1996;15(6):369-381.

4. Marinkovich MP. Laminin 332 in squamous-cell carcinoma. Nat Rev Cancer. 2007;7(5):370-380.

5. Ekblom P, Lonai P, Talts JF. Expression and biological role of laminin-1. Matrix Biol. 2003;22(1):35-47.

6. Garg K, Boppart MD. Influence of exercise and aging on extracellular matrix composition in the skeletal muscle stem cell niche. J Appl Physiol. 2016;121(5):1053-1058. 
7. Burkin DJ, Kim JE, Gu M, et al. Laminin and alpha7beta1 integrin regulate agrin-induced clustering of acetylcholine receptors. J Cell Sci. 2000;113(Pt 16):2877-2886

8. Wong TS, Booth FW. Skeletal muscle enlargement with weight-lifting exercise by rats. J Appl Physiol. 1988;65(2):950-954.

9. Maffiuletti NA, Marc Roig, Eleftherios Karatzanos, et al. Neuromuscular electrical stimulation for preventing skeletal-muscle weakness and wasting in critically ill patients: a systematic review. BMC Med. 2013;11:137.

10. Willand MP, Rosa E, Michalski B, et al. Electrical muscle stimulation elevates intramuscular BDNF and GDNF mRNA following peripheral nerve injury and repair in rats. Neuroscience. 2016;334:93-104.

11. Fukada S, Yamamoto Y, Segawa M, et al. CD90-positive cells, an additional cell population, produce laminin alpha2 upon transplantation to dy(3k)/dy(3k) mice. Exp Cell Res. 2008;314(1):193-203.

12. Vilquin JT, Guérette B, Puymirat J, et al. Myoblast transplantations lead to the expression of the laminin alpha 2 chain in normal and dystrophic (dy/dy) mouse muscles. Gene Ther. 1999;6(5):792-800.

13. Vilquin JT, Kinoshita I, Roy B, et al. Partial laminin alpha2 chain restoration in alpha2 chain-deficient dy/dy mouse by primary muscle cell culture transplantation. J Cell Biol. 1996;133(1):185-197.

14. Durbeej M. Laminins. Cell Tissue Res. 2010;339(1):259-268.

15. Rooney JE, Gurpur PB, Burkin DJ. Laminin-111 protein therapy prevents muscle disease in the mdx mouse model for Duchenne muscular dystrophy. Proc Natl Acad Sci USA. 2009;106(19):7991-7996.

16. Van Ry PM, Minogue P, Hodges BL, et al. Laminin-111 improves muscle repair in a mouse model of merosin-deficient congenital muscular dystrophy. Hum Mol Genet. 2013;23(2):383-396.

17. Goudenege S, Lamarre Y, Dumont N, et al. Laminin-111: a potential therapeutic agent for Duchenne muscular dystrophy. Mol Ther 2010;18(12):2155-2163.

18. Zou K, De Lisio M, Huntsman HD, et al. Laminin-111 improves skeletal muscle stem cell quantity and function following eccentric exercise. Stem Cells Transl Med. 2014;3(9):1013-1022.

19. Gawlik K, Miyagoe Suzuki Y, Ekblom P, et al. Laminin alpha1 chain reduces muscular dystrophy in laminin alpha2 chain deficient mice. Hum Mol Genet. 2004;13(16):1775-1784.

20. Gawlik KI, Durbeej M. Transgenic overexpression of laminin alpha chain in laminin alpha2 chain-deficient mice rescues the disease throughout the lifespan. Muscle Nerve. 2010;42(1):30-37.

21. Zhang BG, Quigley AF, Bourke JL, et al. Combination of agrin and laminin increase acetylcholine receptor clustering and enhance functional neuromuscular junction formation In vitro. Dev Neurobiol. 2016;76(5):551-565.

22. Garg K, Corona BT, Walters TJ. Losartan administration reduces fibrosis but hinders functional recovery after volumetric muscle loss injury. $J$ Appl Physiol (1985). 2014;117(10):1120-1131.

23. Garg K, Ward CL, Hurtgen BJ, et al. Volumetric muscle loss: Persistent functional deficits beyond frank loss of tissue. J Orthop Res. 2015;33(1):40-46.

24. Garg K, Ward CL, Rathbone CR, et al. Transplantation of devitalized muscle scaffolds is insufficient for appreciable de novo muscle fiber regeneration after volumetric muscle loss injury. Cell Tissue Res. 2014;358(3):857-873

25. Hurtgen BJ, Ward CL, Garg K, et al. Severe muscle trauma triggers heightened and prolonged local musculoskeletal inflammation and impairs adjacent tibia fracture healing. J Musculoskelet Neuronal Interact. 2016;16(2):122-134.
26. Dennis RG, Kosnik PE. Excitability and isometric contractile properties of mammalian skeletal muscle constructs engineered in vitro. In Vitro Cell Dev Biol Anim. 2000;36(5):327-335.

27. Lam MT, Huang YC, Birla RK, Takayama S. Microfeature guided skeletal muscle tissue engineering for highly organized 3-dimensional free-standing constructs. Biomaterials. 2009;30(6):1150-1155.

28. Hinds S, Bian W, Dennis RG, et al. The role of extracellular matrix composition in structure and function of bioengineered skeletal muscle. Biomaterials. 2011;32(14):3575-3583.

29. Madden L, Juhas M, Kraus WE, et al. Bioengineered human myobundles mimic clinical responses of skeletal muscle to drugs. Elife. 2015;4:e04885.

30. Gilbert PM, Havenstrite KL, Magnusson KE, et al. Substrate elasticity regulates skeletal muscle stem cell self-renewal in culture. Science. 2010;329(5995):1078-1081.

31. Dubový P, Svízenská I, Jancálek R, et al. Immunohistochemical localization of laminin-1 in the acellular nerve grafts is associated with migrating Schwann cells which display corresponding integrin receptors. Gen Physiol Biophys. 1999;18(Suppl 1):63-65.

32. Hall PE, Lathia JD, Caldwell MA, et al. Laminin enhances the growth of human neural stem cells in defined culture media. BMC Neurosci. 2008;9:71.

33. González Hoyuela M, Barbas JA, Rodríguez Tébar A. The auto regulation of retinal ganglion cell number. Development. 2001;128(1):117124.

34. Barros CS, Franco SJ, Müller U. Extracellular matrix: functions in the nervous system. Cold Spring Harb Perspect Biol. 2011;3(1):a005108.

35. Darabid H, Perez Gonzalez AP, Robitaille R. Neuromuscular synaptogenesis: coordinating partners with multiple functions. Nat Rev Neurosci. 2014;15(11):703-718

36. Noakes PG, Gautam M, Mudd J, et al. Aberrant differentiation of neuromuscular junctions in mice lacking s-laminin/laminin beta 2. Nature. 1995;374(6519):258-262.

37. Patton BL, Cunningham JM, Thyboll J, et al. Properly formed but improperly localized synaptic specializations in the absence of laminin alpha4. Nat Neurosci. 2001;4(6):597-604.

38. Burkin DJ, Gu M, Hodges BL, et al. A functional role for specific spliced variants of the alpha7beta1 integrin in acetylcholine receptor clustering. J Cell Biol. 1998;143(4):1067-1075.

39. Sugiyama JE, Glass DJ, Yancopoulos GD, et al. Laminin-induced acetylcholine receptor clustering: an alternative pathway. $J$ Cell Biol. 1997;139(1):181-191.

40. Zhang BG, Quigley AF, Bourke JL, et al. Combination of agrin and laminin increase acetylcholine receptor clustering and enhance functional neuromuscular junction formation In vitro. Dev Neurobiol. 2016;76(5):551-565

41. Swindle Reilly KE, Papke JB, Kutosky HP, et al. The impact of laminin on 3D neurite extension in collagen gels. J Neural Eng. 2012;9(4):046007.

42. Toba T, Nakamura T, Shimizu Y, et al. Regeneration of canine peroneal nerve with the use of a polyglycolic acid-collagen tube filled with laminin-soaked collagen sponge: a comparative study of collagen sponge and collagen fibers as filling materials for nerve conduits. $J$ Biomed Mater Res. 2001;58(6):622-630.

43. Wang B, Yuan J, Chen X, et al. Functional regeneration of the transected recurrent laryngeal nerve using a collagen scaffold loaded with laminin and laminin-binding BDNF and GDNF. Sci Rep. 2016;6:32292.

44. Suri S, Schmidt CE. Cell-laden hydrogel constructs of hyaluronic acid, collagen, and laminin for neural tissue engineering. Tissue Eng Part A. 2010;16(5):1703-1716. 
45. Marquardt L, Willits RK. Student award winner in the undergraduate's degree category for the Society for Biomaterials 35th Annual Meeting, Orlando, Florida, April 13-16, 2011. Neurite growth in PEG gels: effect of mechanical stiffness and laminin concentration. J Biomed Mater Res A. 2011;98(1):1-6.

46. Francisco AT, Hwang PY, Jeong CG, et al. Photocrosslinkable laminin-functionalized polyethylene glycol hydrogel for intervertebral disc regeneration. Acta Biomater. 2014;10(3):1102-1111.

47. Koh HS, Yong T, Chan CK, et al. Enhancement of neurite outgrowth using nano-structured scaffolds coupled with laminin. Biomaterials. 2008;29(26):3574-3582.

48. Zhao C, Deng W, Gage FH. Mechanisms and functional implications of adult neurogenesis. Cell. 2008;132(4):645-660.

49. Kazanis I, ffrench Constant C. Extracellular matrix and the neural stem cell niche. Dev Neurobiol. 2011;71(11):1006-1017.

50. Ajioka I, Jinnou H, Okada K, et al. Enhancement of neuroblast migration into the injured cerebral cortex using laminin-containing porous sponge. Tissue Eng Part A. 2015;21(1-2):193-201.

51. Jurga M, Dainiak MB, Sarnowska A, et al. The performance of laminin-containing cryogel scaffolds in neural tissue regeneration. Biomaterials. 2011;32(13):3423-3434.

52. Stabenfeldt SE, García AJ, LaPlaca MC. Thermoreversible laminin-functionalized hydrogel for neural tissue engineering. J Biomed Mater Res A. 2006;77(4):718-725.

53. Addington CP, Heffernan JM, Millar Haskell CS, et al. Enhancing neural stem cell response to SDF-1alpha gradients through hyaluronic acid-laminin hydrogels. Biomaterials. 2015;72:11-19.

54. Hou S, Xu Q, Tian W, et al. The repair of brain lesion by implantation of hyaluronic acid hydrogels modified with laminin. J Neurosci Methods. 2005;148(1):60-70.

55. Arulmoli J, Wright HJ, Phan DT, et al. Combination scaffolds of salmon fibrin, hyaluronic acid, and laminin for human neural stem cell and vascular tissue engineering. Acta Biomater. 2016;43:122-138.

56. Urban JP, Roberts S. Degeneration of the intervertebral disc. Arthritis Res Ther. 2003;5(3):120-130.

57. Hwang PY, Chen J, Jing L, et al. The role of extracellular matrix elasticity and composition in regulating the nucleus pulposus cell phenotype in the intervertebral disc: a narrative review. $J$ Biomech Eng. 2014;136(2):021010.
58. Francisco AT, Mancino RJ, Bowles RD, et al. Injectable laminin-functionalized hydrogel for nucleus pulposus regeneration. Biomaterials. 2013;34(30):7381-7388.

59. Arnaoutova I, vGeorge J, Kleinman HK, et al. The endothelial cell tube formation assay on basement membrane turns 20: state of the science and the art. Angiogenesis. 2009;12(3):267-274.

60. Stamati K, Priestley JV, Mudera V, et al. Laminin promotes vascular network formation in $3 \mathrm{D}$ in vitro collagen scaffolds by regulating VEGF uptake. Exp Cell Res. 2014;327(1):68-77.

61. Williams SK, Kleinert LB, Patula Steinbrenner V. Accelerated neovascularization and endothelialization of vascular grafts promoted by covalently bound laminin type 1. J Biomed Mater Res A. 2011;99(1):67-73.

62. Ye C, Wang Y, Su H, et al. Construction of a fucoidan/laminin functional multilayer to direction vascular cell fate and promotion hemocompatibility. Mater Sci Eng C Mater Biol Appl. 2016;64:236-242.

63. Ali S, Saik JE, Gould DJ, et al. Immobilization of cell-adhesive laminin peptides in degradable pegda hydrogels influences endothelial cell tubulogenesis. Biores Open Access. 2013;2(4):241-249.

64. Balaoing LR, Post AD, Lin AY, et al. Laminin peptide-immobilized hydrogels modulate valve endothelial cell hemostatic regulation. PLoS One. 2015;10(6): $\mathrm{e} 0130749$.

65. Koh LB, Islam MM, Mitra D, et al. Epoxy cross-linked collagen and collagen-laminin Peptide hydrogels as corneal substitutes. J Funct Biomater. 2013;4(3):162-177.

66. Nakaji Hirabayashi T, Kato K, Iwata H. In vivo study on the survival of neural stem cells transplanted into the rat brain with a collagen hydrogel that incorporates laminin-derived polypeptides. Bioconjug Chem. 2013;24(11):1798-1804.

67. Gilbert PM, Havenstrite KL, Magnusson KE, et al. Substrate elasticity regulates skeletal muscle stem cell self-renewal in culture. Science. 2010;329(5995):1078-1081.

68. Gardiner NJ, Fernyhough P, Tomlinson DR, et al. Alpha7 integrin mediates neurite outgrowth of distinct populations of adult sensory neurons. Mol Cell Neurosci. 2005;28(2):229-240.

69. Jeon H, Lee JY, Lee H, et al. Nanostructured surface of electrospun PCL/ dECM fibres treated with oxygen plasma for tissue engineering. RSC Advances. 2016;6(39):32887-32896. 